\title{
High quality, small molecule-activity datasets for kinase
}

\section{research [version 1; peer review: 2 approved]}

\author{
Rajan Sharma1, Stephan C. Schürer ${ }^{2}$, Steven M. Muskal1
}

${ }^{1}$ Eidogen-Sertanty, Inc., Oceanside, CA, 92056, USA

2Department of Pharmacology, Miller School of Medicine and Center for Computational Science, University of Miami, Miami, FL, 33136, USA

V1 First published: 14 Jun 2016, 5(Chem Inf Sci):1366 https://doi.org/10.12688/f1000research.8950.1

Second version: 20 Jul 2016, 5(Chem Inf Sci):1366 https://doi.org/10.12688/f1000research.8950.2

Latest published: 26 Oct 2016, 5(Chem Inf Sci):1366 https://doi.org/10.12688/f1000research.8950.3

\section{Abstract}

Kinases regulate cell growth, movement, and death. Deregulated kinase activity is a frequent cause of disease. The therapeutic potential of kinase inhibitors has led to large amounts of published structure activity relationship (SAR) data. Bioactivity databases such as the Kinase Knowledgebase (KKB), WOMBAT, GOSTAR, and ChEMBL provide researchers with quantitative data characterizing the activity of compounds across many biological assays. The KKB, for example, contains over $1.8 \mathrm{M}$ kinase structure-activity data points reported in peer-reviewed journals and patents. In the spirit of fostering methods development and validation worldwide, we have extracted and have made available from the KKB $258 \mathrm{~K}$ structure activity data points and $76 \mathrm{~K}$ associated unique chemical structures across eight kinase targets. These data are freely available for download within this data note.

\section{Keywords}

Kinase, SAR, Bioactivity Database, Dataset, Drug Discovery, Bioactive Molecules, Kinase Knowledgebase, KKB

= chencacat Mhis article is included in the Chemical Information Science gateway.

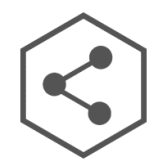

This article is included in the Data: Use and Reuse collection.

\author{
Open Peer Review \\ Approval Status \\ 1 \\ 2 \\ version 3 \\ (revision) \\ 26 Oct 2016 \\ version 2 \\ (revision) \\ 20 Jul 2016 \\ version 1 \\ 14 Jun 2016

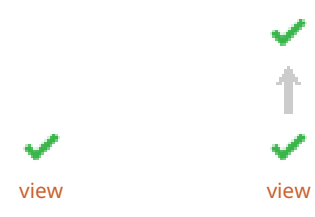 \\ 1. George Nicola, University of California at San \\ Diego, San Diego, USA \\ 2. Sorin Avram ID, Institute of Chemistry \\ Timisoara of the Romanian Academy (ICT), \\ Timișoara, Romania \\ Any reports and responses or comments on the \\ article can be found at the end of the article.
}


Corresponding author: Steven M. Muskal (smuskal@eidogen-sertanty.com)

Competing interests: No competing interests were disclosed.

Grant information: The work of SCS was supported by grant U54CA189205 (Illuminating the Druggable Genome Knowledge Management Center, IDG-KMC). The IDG-KMC is a component of the Illuminating the Druggable Genome (IDG) project and NIH Common Fund project, awarded by the NCI.

Copyright: ( 2016 Sharma R et al. This is an open access article distributed under the terms of the Creative Commons Attribution License, which permits unrestricted use, distribution, and reproduction in any medium, provided the original work is properly cited. Data associated with the article are available under the terms of the Creative Commons Zero "No rights reserved" data waiver (CC0 1.0 Public domain dedication).

How to cite this article: Sharma R, Schürer SC and Muskal SM. High quality, small molecule-activity datasets for kinase research [version 1; peer review: 2 approved] F1000Research 2016, 5(Chem Inf Sci):1366 https://doi.org/10.12688/f1000research.8950.1

First published: 14 Jun 2016, 5(Chem Inf Sci):1366 https://doi.org/10.12688/f1000research.8950.1 


\section{Introduction}

Since their discovery in 1975 by Cohen et al. ${ }^{1}$, kinases are now one of the most established drug target families, second only to G-protein-coupled receptors (GPCRs). Most progress in kinase research has occurred in the last 25 years including the discovery of many new kinases ${ }^{2,3}$, identification of new isoforms of preexisting kinases ${ }^{4,5}$, elucidation of new biological pathways, and identification of many new kinase-disease associations ${ }^{6,7}$. While kinases are well-validated anti-cancer targets ${ }^{8-11}$, kinase inhibitors also have been pursued in cardiovascular ${ }^{12}$, autoimmune ${ }^{13}$, inflammatory skin and bowel ${ }^{14}$, neurodegenerative ${ }^{15}$, and renal disease programs ${ }^{16}$. Most small-molecule kinase inhibitors target the ATP binding site of the kinase catalytic domain ${ }^{11}$. The ATP binding region of the catalytic domain is highly conserved among protein kinases, which has important consequences for drug development. Achieving selectivity of a small molecule inhibitor against kinase off-targets to avoid adverse reactions can be a major hurdle. However, the cross reactivity of many chemotypes can also open opportunities to focus on other closely related kinases. Despite the high degree of conservation in the ATP binding site, reasonably selective inhibitors with favorable pharmacological properties can be developed ${ }^{17}$. It is now common in discovery programs to profile inhibitors against an extensive set of kinase targets ${ }^{18}$. These kinase-profiling efforts have generated valuable data, providing insight into selectivity and promiscuity of clinical inhibitors ${ }^{19-21}$.

Medicinal chemists can benefit significantly from well-curated databases documenting chemical structure(s) with an experimentally measured biological activity. These structure and activity databases or SAR databases help to better understand drug-target interaction, which can assist in the design of potent and selective chemical inhibitors ${ }^{22-25}$. A well populated, editable, easy to search and flexible SAR database is an integral part of the modern drug design process $^{26}$. SAR databases provide elementary insights to researchers, including:

(a) Target druggability: known small molecule binders are required to categorize a protein as druggable. High-affinity and non-promiscuous inhibitors are particularly valuable to establish druggability; and can be further validated using structure biology information. In many cases druggability can be inferred for new targets using homology models ${ }^{27}$ where similarities can be mapped via sequences, pathways or functions. Examples include the Target Informatics Platform (TIP) ${ }^{28}$ and Modbase ${ }^{29}$.

(b) Scaffold selectivity: the golden principle that applies is "less selective scaffolds have more undesirable side effects." A prior knowledge of selectivity profiles can help in making informed decisions on which chemotypes to pursue at the start of discovery programs ${ }^{30}$. Organizing data by scaffold enables classic SAR analysis in which side-chain moieties can be evaluated and considered or avoided in lead optimization ${ }^{31}$. (c) Clinical molecules: it can be very helpful to see scaffold(s) or derivatives under the study of launched drugs. This enables medicinal chemists to associate therapeutic classes with active scaffolds.

(d) Development and validation of computational methods: well-curated datasets are very helpful in the development and refinement of computational methodologies. With a common set of data, computational researchers can also compare and contrast methods, providing additional validation $^{32}$.

(e) Virtual screening: high-quality, well-curated, standardized and annotated datasets are required to build predictive models for virtual screening as we have shown previously specifically for the Kinase Knowledgebase (KKB) data ${ }^{33}$.

\section{Kinase Knowledgebase (KKB)}

The KKB is a database of biological activity data, structureactivity relationships, and chemical synthesis data focused on protein kinases. Since its inception in 2001, the KKB has grown steadily with quarterly updates each year. With more than two decades of high quality SAR data, the KKB represents one of the first kinase target specific databases of biological activity and chemical synthesis data from curated scientific literature and patents. The KKB contains a large number of kinase structure-activity data points $(>1.8 \mathrm{M})$ reported in peer-reviewed literature covering journals and patents. The data have been curated from over 150 different journals reporting kinase inhibitors with activity data, with leading contributions from J Med Chem, Bioorg Med Chem, Bioorg Med ChemLett and Euro J Med Chem. In addition, the KKB contains data curated from patents/applications from WO, EP and US. The scientific information is curated from the published text using a combination of automatic and manual efforts.

A summary of the first quarter release for year 2016 (Q1-2016) is reported in Table 1. With the Q1-2016 KKB release, there are total of 506 unique kinase targets with over $682 \mathrm{~K}$ unique small molecules. A listing of few "hot" kinase targets with their inhibitors (data points) is reported in Table 2.

Table 1. Eidogen-Sertanty Kinase Knowledgebase. Summary Statistics - Q1 2016 Release.

\begin{tabular}{|l|r|}
\hline Articles covered: & 2,780 \\
\hline Patents and patent applications covered: & 6,346 \\
\hline Total Number of Bio-activity data points: & $1,775,368$ \\
\hline Total Number of unique molecules: & 682,289 \\
\hline Total Number of unique molecules w/ assay data: & 337,491 \\
\hline Total Number of assay protocols: & 32,462 \\
\hline
\end{tabular}


Table 2. Eidogen-Sertanty Kinase Knowledgebase. Data Points for Selected Targets- Q1 2016 Release.

\begin{tabular}{|c|c|c|c|c|c|c|c|c|}
\hline $\begin{array}{l}\text { Kinase } \\
\text { Classification }\end{array}$ & Family & Target Name & $\begin{array}{l}\text { All } \\
\text { SAR } \\
\text { Data } \\
\text { Points }\end{array}$ & $\begin{array}{l}\text { All } \\
\text { IC50 } \\
\text { Data } \\
\text { Points }\end{array}$ & $\begin{array}{l}\text { Unique } \\
\text { Assay } \\
\text { Molecules }\end{array}$ & $\begin{array}{l}\text { All } \\
\text { SAR } \\
\text { Data } \\
\text { Points }\end{array}$ & $\begin{array}{l}\text { All } \\
\text { IC50 } \\
\text { Data } \\
\text { Points }\end{array}$ & $\begin{array}{l}\text { Unique } \\
\text { Assay } \\
\text { Molecules }\end{array}$ \\
\hline \multirow{10}{*}{$\begin{array}{l}\text { Non-Receptor } \\
\text { Tyrosine Kinases }\end{array}$} & Abl & ABL1 & 14750 & 4843 & 2177 & 4237 & 1836 & 1098 \\
\hline & Csk & CSK & 3792 & 1448 & 450 & 548 & 266 & 146 \\
\hline & Fak & FAK/PTK2 & 10311 & 4067 & 3863 & 2880 & 1306 & 1300 \\
\hline & JakA & JAK3 & 29550 & 8778 & 11456 & 1327 & 605 & 440 \\
\hline & \multirow[b]{3}{*}{ Src } & SRC & 21936 & 8289 & 4480 & 3425 & 1473 & 747 \\
\hline & & LCK & 23819 & 10514 & 6090 & 784 & 381 & 214 \\
\hline & & FYN & 3125 & 873 & 151 & 28 & 11 & 7 \\
\hline & \multirow[b]{2}{*}{ Syk } & SYK & 39426 & 17549 & 16774 & 1037 & 484 & 268 \\
\hline & & ZAP70 & 5951 & 2998 & 1013 & 5 & 2 & 2 \\
\hline & Tec & ITK & 10131 & 3690 & 2197 & 219 & 83 & 113 \\
\hline \multirow{13}{*}{$\begin{array}{l}\text { Receptor } \\
\text { Tyrosine Kinases }\end{array}$} & \multirow[b]{2}{*}{ EGFR } & EGFR & 34293 & 14684 & 6593 & 19731 & 9068 & 3321 \\
\hline & & ERBB2 & 11182 & 5199 & 1756 & 7988 & 4115 & 1803 \\
\hline & Eph & EPHA2 & 2935 & 765 & 223 & 12 & 0 & 1 \\
\hline & FGFR & FGFR1 & 19582 & 8394 & 4149 & 8781 & 3345 & 1622 \\
\hline & InsR & INSR & 4607 & 1293 & 1032 & 920 & 422 & 395 \\
\hline & Met & MET & 27032 & 10406 & 9308 & 5147 & 2526 & 1983 \\
\hline & \multirow[b]{3}{*}{ PDGFR } & PDGFRB & 14058 & 5889 & 2388 & 5426 & 2653 & 983 \\
\hline & & FLT3/FLK2 & 13082 & 3974 & 2830 & 10224 & 4386 & 2268 \\
\hline & & KIT & 14991 & 5153 & 2527 & 7040 & 3339 & 2747 \\
\hline & Tie & TEK & 9142 & 4306 & 2300 & 3122 & 1561 & 1360 \\
\hline & Trk & $\begin{array}{l}\text { NTRK1/ } \\
\text { TRKA }\end{array}$ & 8199 & 3207 & 2925 & 1743 & 814 & 563 \\
\hline & \multirow[b]{2}{*}{ VEGFR } & KDR/FLK1 & 55991 & 24821 & 13899 & 20317 & 9119 & 6541 \\
\hline & & FLT1 & 9963 & 4251 & 1116 & 864 & 432 & 197 \\
\hline \multirow{8}{*}{ CMGC Kinases } & \multirow[b]{2}{*}{ CDK } & CDK2 & 33878 & 12695 & 10411 & 5344 & 1119 & 667 \\
\hline & & CDK5 & 8227 & 3048 & 1714 & 18 & 3 & 3 \\
\hline & GSK & GSK3B & 22950 & 7766 & 6992 & 2013 & 519 & 832 \\
\hline & \multirow[b]{5}{*}{ MAPK } & MAPK14 & 36067 & 16077 & 14270 & 6541 & 2373 & 2787 \\
\hline & & MAPK1 & 11286 & 3073 & 3081 & 2725 & 1064 & 1085 \\
\hline & & MAPK10 & 5725 & 1615 & 1610 & 96 & 48 & 23 \\
\hline & & MAPK8 & 6225 & 1803 & 1523 & 880 & 285 & 393 \\
\hline & & MAPK11 & 1162 & 196 & 100 & 0 & 0 & 0 \\
\hline \multirow{5}{*}{ AGC Kinases } & AKT & AKT1 & 14601 & 6333 & 5794 & 6970 & 3064 & 2831 \\
\hline & DMPK & ROCK1 & 9135 & 2052 & 3105 & 189 & 40 & 65 \\
\hline & PKB & PDPK1 & 9569 & 3765 & 2642 & 148 & 68 & 44 \\
\hline & & PRKCA & 10670 & 3528 & 2588 & 5477 & 669 & 510 \\
\hline & PKC & PRKCE & 3759 & 1494 & 1032 & 2 & 1 & 1 \\
\hline \multirow{3}{*}{ CAMK Kinases } & CAMKL & CHEK1 & 13724 & 5192 & 5202 & 3140 & 220 & 1130 \\
\hline & \multirow[b]{2}{*}{ MAPKAPK } & MAPKAPK2 & 11041 & 4073 & 3747 & 1311 & 649 & 637 \\
\hline & & MAPKAPK3 & 2138 & 518 & 299 & 0 & 0 & 0 \\
\hline
\end{tabular}




\begin{tabular}{|c|c|c|c|c|c|c|c|c|}
\hline $\begin{array}{l}\text { Kinase } \\
\text { Classification }\end{array}$ & Family & Target Name & $\begin{array}{l}\text { All } \\
\text { SAR } \\
\text { Data } \\
\text { Points }\end{array}$ & $\begin{array}{l}\text { All } \\
\text { IC50 } \\
\text { Data } \\
\text { Points }\end{array}$ & $\begin{array}{l}\text { Unique } \\
\text { Assay } \\
\text { Molecules }\end{array}$ & $\begin{array}{l}\text { All } \\
\text { SAR } \\
\text { Data } \\
\text { Points }\end{array}$ & $\begin{array}{l}\text { All } \\
\text { IC50 } \\
\text { Data } \\
\text { Points }\end{array}$ & $\begin{array}{l}\text { Unique } \\
\text { Assay } \\
\text { Molecules }\end{array}$ \\
\hline \multirow{8}{*}{$\begin{array}{l}\text { Other Protein } \\
\text { Kinases }\end{array}$} & AUR & AURKA & 22646 & 7904 & 7034 & 1128 & 474 & 382 \\
\hline & & IKBKB & 7628 & 2978 & 3146 & 367 & 83 & 144 \\
\hline & IKK & $\begin{array}{l}\text { CHUK/ } \\
\text { IKBKA }\end{array}$ & 2938 & 999 & 764 & 296 & 148 & 147 \\
\hline & PLK & PLK1 & 9181 & 3223 & 3480 & 2986 & 1364 & 888 \\
\hline & STE & MAP2K1 & 6340 & 2551 & 2045 & 1651 & 573 & 655 \\
\hline & \multirow[b]{3}{*}{ TKL } & ILK & 360 & 180 & 172 & 581 & 253 & 80 \\
\hline & & RAF1 & 11302 & 5058 & 3378 & 1956 & 885 & 581 \\
\hline & & BRAF & 26349 & 12169 & 8983 & 6726 & 2442 & 2106 \\
\hline \multirow{4}{*}{$\begin{array}{l}\text { Other Non-Protein } \\
\text { Kinases }\end{array}$} & \multirow{2}{*}{$\begin{array}{l}\text { Lipid } \\
\text { Kinases }\end{array}$} & $\begin{array}{l}\text { PIK3/ } \\
\text { PIK3CG }\end{array}$ & 29925 & 13438 & 10899 & 3525 & 1758 & 1217 \\
\hline & & PIK3CA & 36168 & 16418 & 12448 & 3392 & 1310 & 1219 \\
\hline & \multirow{2}{*}{$\begin{array}{l}\text { Nucleotide } \\
\text { Kinases }\end{array}$} & TK1 & 1106 & 301 & 339 & 2416 & 533 & 193 \\
\hline & & ADK & 1924 & 931 & 723 & 669 & 252 & 240 \\
\hline
\end{tabular}

Kinase inhibitors are biologically active small molecules and their activity refers to experimentally measured data on a given kinase target (in enzyme or in cell based assays), using predefined experimental protocols. After curation and standardization, these measured values together with related information are indexed in the $\mathrm{KKB}$. Each inhibitor entered in the KKB carries unique identifiers such as:

(a) Chemical information and biological information: unique structure IDs (MR_ID) are assigned based on unique canonical SMILES. In addition hand-drawn Cartesian coordinates are captured. Chemical compounds are associated with calculated chemical and physical properties.

(b) Biological target and assay protocol: biological targets are annotated by EntrezGeneID, UniProt ID, and HUGO approved names. An assay protocol includes detailed information pertaining to the experiments performed to measure the biological activity for the compound. Each protocol has a descriptive title and a unique set of keywords. Assays are categorized by assay format (biochemical, cell-based, etc.) following standards set forth by BioAssay Ontology $(\mathrm{BAO})^{34,35}$. Kinase targets are classified by protein and non-protein kinases and protein kinases by the typical domain-based classification into group, family, etc. We are in the process of mapping KKB targets to the Drug Target Ontology (DTO), which is in development.

(c) Experimental bioactivity screening results. A bioactivity data point is a defined result/endpoint of a specified small molecule compound tested in a biological assay. The assay is defined in b); result type/endpoint captured include $\mathrm{IC}_{50}$, $\mathrm{K}_{\mathrm{i}}, \mathrm{K}_{\mathrm{d}}$; the vast majority for biochemical and cell-based assays correspond to BAO definitions. (d) Source reference: bibliographic information and unique identifiers for journal article and patents from which information related to the molecules was extracted include PubMedID, DOI, and standardized patent numbers. For journals, the KKB provides title, authors name, journal-name, volume, issues, and page numbers. For patents their titles, patent or patent application number (along with family members), inventor's names, assignee names, publication data and priority numbers are provided.

It is observed that a disease type can be related to multiple kinase groups, and several diseases can arise from a common set of kinase group (Table 3$)^{6}$. In the KKB, kinases are classified by protein and

Table 3. Kinase-disease association in top therapeutic segments.

\begin{tabular}{|l|l|}
\hline Disease Class & Kinase Group \\
\hline Cancer & $\begin{array}{l}\text { AGC;atypical;CAMK;CK1; } \\
\text { CMGC;RGC;STE;TK;TKL }\end{array}$ \\
\hline Diabetes & AGC;CMGC;TK \\
\hline Cardiovascular & AGC;CAMK;CMGC;TKL \\
\hline Hypertension & AGC;CAMK;RGC \\
\hline Neurodegeneration & AGC;CAMK;CMGC;CK1 \\
\hline Inflammation & CMGC;STE;TKL \\
\hline Immunity & AGC;TK \\
\hline
\end{tabular}


non-protein kinases with several sub-categories such as carbohydrate and lipid kinase and the typical protein kinase groups (such CMGC, CAMK, TK, TKL, RGC, AGC) and further sub-groups such as families. DTO provides a functional and phylogenetic classification of kinase domains to facilitate navigation of kinase drug targets. DTO is developed as part of the Illuminating the Druggable Genome (IDG) project. Here we make datasets freely available for the research community including to support efforts such as IDG. We also offer to run our predictive models built using KKB data to support prioritization of drug targets.

\section{Kinase inhibitor datasets}

The wealth of kinase inhibitor data presents opportunities for analysis as a whole or by integrating such data into various computational platforms to support development and validation of hypotheses of kinase inhibition. Several years ago, Eidogen-Sertanty made available $3880 \mathrm{pIC}_{50}$ data points across three kinase targets (ABL1, SRC, and AURKA - validation sets) to foster algorithm development and validation worldwide. With this data note, eight additional targets comprising inhibitors for therapeutically important classes: EGFR, CDK2, ROCK2, MAPK14 and PI3K (class I catalytic) (Table 4) totaling $\sim 258 \mathrm{~K}$ data points (structure with standard results/endpoints such as $\mathrm{IC}_{50}, \mathrm{~K}_{\mathrm{i}}$ or $\mathrm{K}_{\mathrm{d}}$ ) and $\sim 76 \mathrm{~K}$ unique chemical structures now have been made available to further foster worldwide development, validation, and collaborative interaction (see KB_SAR_DATA_F1000.txt and KB_SAR_DATA_F1000.sdf files). These datapoints have been exported from the KKB and survey 1044 articles and 942 patents respectively.

The datasets cover a broad range of biochemical and cell based studies investigating kinase inhibition; and they represent a diverse collection of pharmaceutically active scaffolds. These scaffolds can be easily examined for selectivity and specificity for the given eight kinase targets. Additionally, they can be used to infer novel targetinhibitor relationships for kinases and compounds not included in these subsets.

Bibliographic information is reported in the files ArticleInfo_F1000. txt and PatentInfo_F1000.txt. Experimental procedure along with metadata information for targets including EntrezGeneIDs, assay format/type (biochemical/enzyme, cell based, etc), keywords, species, and cell lines used in cell-based data are stored in AssayProtocols_F1000 (txt and xml attached).

The KKB validation sets have a maximum contribution from EGFR with nearly $\sim 54 \mathrm{~K}$ inhibitors molecules. This is followed by $\sim 43 \mathrm{~K}$ inhibitors for MAPK14; CDK2 and PIK3CA each have $\sim 39 \mathrm{~K}$ inhibitors. Figure 1 depicts data point distributions for each kinase in the attached subset. Moreover, $84 \%$ of the data are from biochemical enzyme based assay experiments, and $16 \%$ of the data from cell-based assays (in Figure 2). The datapoint measures include $\mathrm{IC}_{50}, \mathrm{~K}_{\mathrm{i}}$ and $\mathrm{K}_{\mathrm{d}}$ (Figure 3).

Table 4. Important aspects about the selected targets.

\begin{tabular}{|c|c|c|c|c|c|}
\hline Kinase & Approved Name & Class & Diseases Associated & $\begin{array}{l}\text { Entrez } \\
\text { GenelD }\end{array}$ & $\begin{array}{l}\text { Uniprot } \\
\text { ID }\end{array}$ \\
\hline EGFR* $^{*}$ & $\begin{array}{l}\text { Epidermal Growth Factor } \\
\text { Receptor }\end{array}$ & $\begin{array}{l}\text { Receptor Tyrosine } \\
\text { Kinase }\end{array}$ & $\begin{array}{l}\text { NSCLC, Medullary Thyroid } \\
\text { Cancer, Breast Cancer, } \\
\text { Neonatal Inflammatory Skin } \\
\text { and Bowel Disease }\end{array}$ & 1956 & P00533 \\
\hline CDK2 & Cyclin-Dependent Kinase 2 & $\begin{array}{l}\text { Serine/Threonine } \\
\text { Kinase }\end{array}$ & Angiomyoma, Carbuncle & 1017 & P24941 \\
\hline ROCK2 & $\begin{array}{l}\text { Rho-Associated, Coiled-Coil } \\
\text { Containing Protein Kinase } 2\end{array}$ & $\begin{array}{l}\text { Serine/Threonine } \\
\text { Kinase }\end{array}$ & $\begin{array}{l}\text { Colorectal Cancer, Penile } \\
\text { Disease, Hepatocellular } \\
\text { Carcinoma }\end{array}$ & 9475 & O75116 \\
\hline MAPK14 & $\begin{array}{l}\text { Mitogen-Activated Protein } \\
\text { Kinase } 14\end{array}$ & $\begin{array}{l}\text { Serine/Threonine } \\
\text { Kinase }\end{array}$ & $\begin{array}{l}\text { Acquired Hyperkeratosis, } \\
\text { Prostate Transitional Cell } \\
\text { Carcinoma, Immunity-related } \\
\text { Diseases }\end{array}$ & 1432 & Q16539 \\
\hline PIK3CA & $\begin{array}{l}\text { Phosphatidylinositol-4,5- } \\
\text { Bisphosphate 3-Kinase, } \\
\text { Catalytic Subunit Alpha }\end{array}$ & Lipid Kinase & $\begin{array}{l}\text { Colorectal Cancer, Actinic } \\
\text { Keratosis }\end{array}$ & 5290 & P42336 \\
\hline PIK3CB & $\begin{array}{l}\text { Phosphatidylinositol-4,5- } \\
\text { Bisphosphate 3-Kinase, } \\
\text { Catalytic Subunit Beta }\end{array}$ & Lipid Kinase & - & 5291 & P42338 \\
\hline PIK3CD & $\begin{array}{l}\text { Phosphatidylinositol-4,5- } \\
\text { Bisphosphate 3-Kinase, } \\
\text { Catalytic Subunit Delta }\end{array}$ & Lipid Kinase & $\begin{array}{l}\text { Immunodeficiency 14, } \\
\text { Activated PIK3-Delta } \\
\text { Syndrome }\end{array}$ & 5293 & 000329 \\
\hline PIK3CG & $\begin{array}{l}\text { Phosphatidylinositol-4,5- } \\
\text { Bisphosphate 3-Kinase, } \\
\text { Catalytic Subunit Gamma }\end{array}$ & Lipid Kinase & Lichen Nitidus & 5294 & P48736 \\
\hline
\end{tabular}

*Afatinib, Erlotinib, Gefitinib, Lapatinib, Osimertinib, Vandetanib are US-FDA approved kinase inhibitors with EGFR as one of the valid targets. 
Analysis of $\sim 76 \mathrm{~K}$ unique molecules for selectivity against targets reveals that $\sim 64 \mathrm{~K}$ inhibit only one kinase of the eight kinases extracted (Figure 4). Approximately $5 \mathrm{~K}$ molecules show activity against two kinase targets, and $\sim 3 \mathrm{~K}$ molecules show activity against three kinases. A total of 79 molecules in the subset have some activity against all the eight kinase targets.
Dataset 1. High quality, small molecule-activity for kinase research. Raw data behind the analyses described in the Data Note are included

http://dx.doi.org/10.5256/f1000research.8950.d124591

The file 'Datasets legends' contains descriptions for each dataset.

\section{Datapoints: Kinase Breakup}

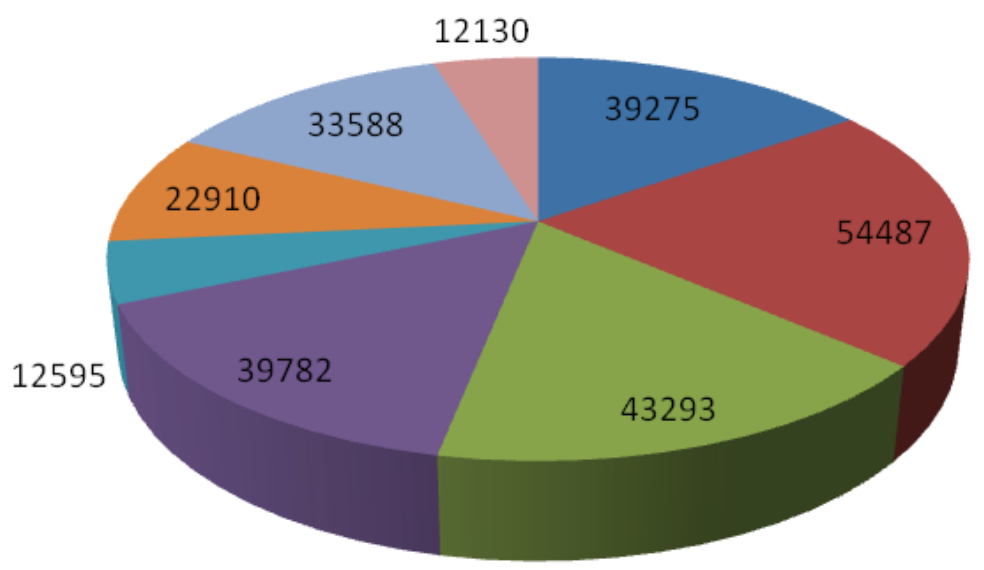
- CDK2
口EFR
MAPK14
PIK3CA
PIK3CB
- PIK3CD
PIK3CG
ROCK2

Figure 1. Data point distributions for each kinase.

\section{Datapoints: Assay Breakup}

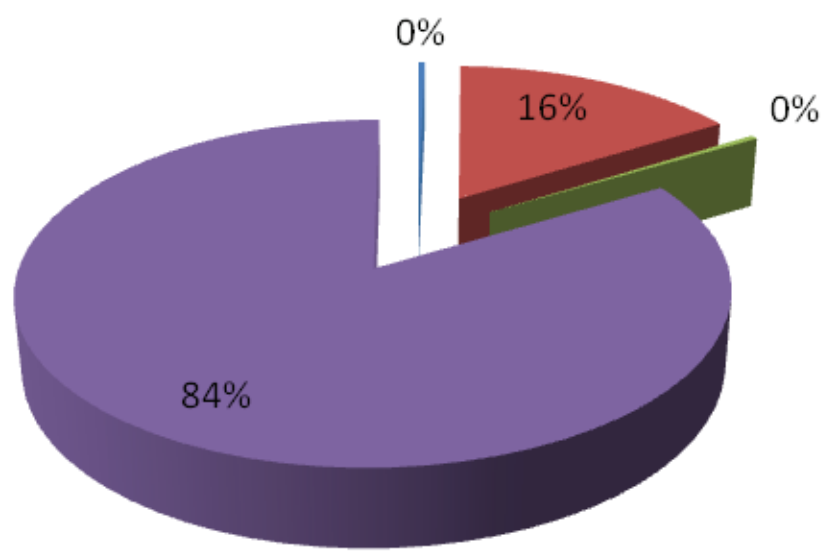

Animal Model

Cell-Based

Cell-Free

Enzyme

Figure 2. Data points share for each assay type. 


\section{Datapoints: Assay Measure}

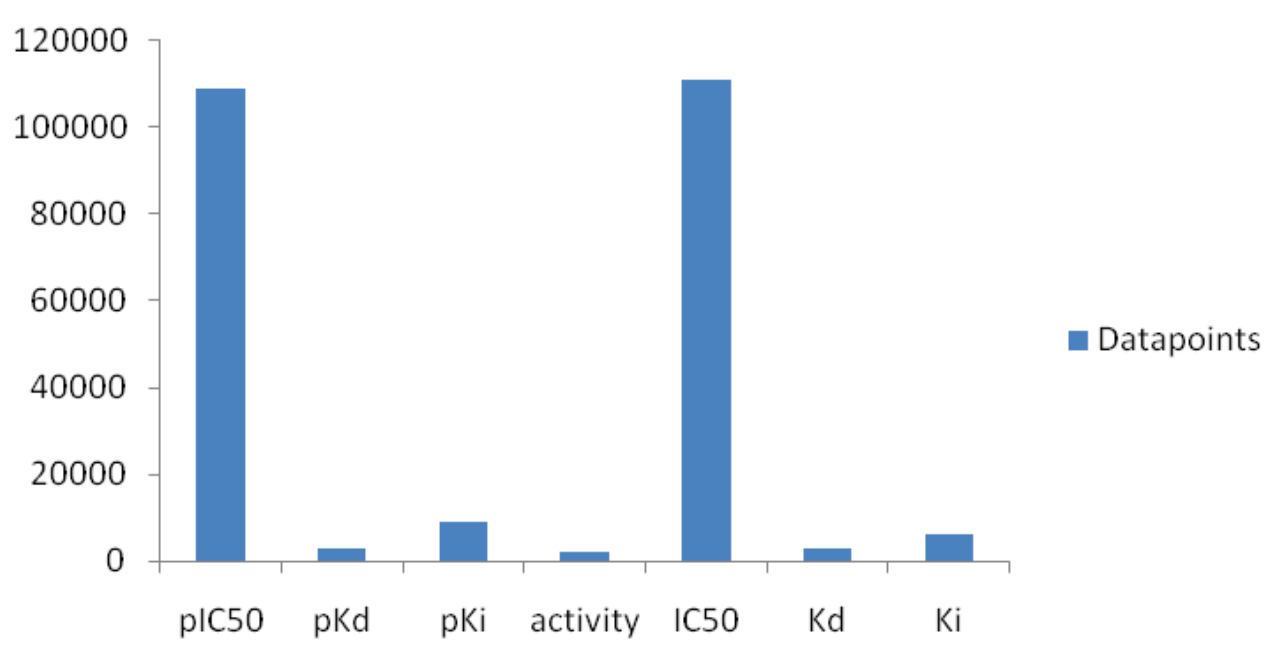

Figure 3. Data points in various assay measures.

\section{Selectivity Profile}

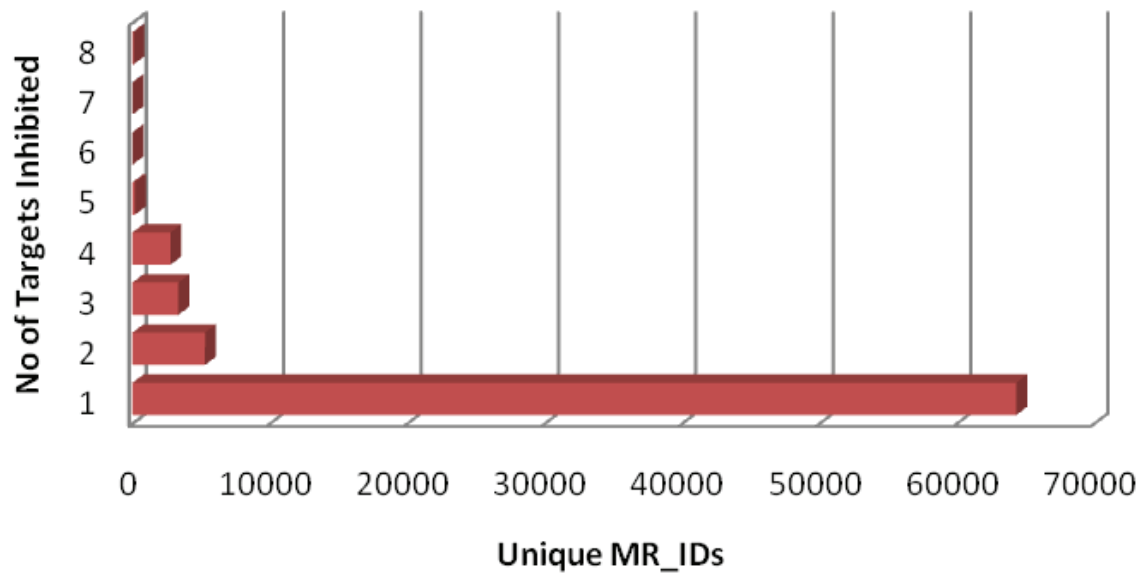

Figure 4. Selectivity profile for data points.

\section{Conclusions}

The KKB is available in various formats such as SQL, SDF and IJC format (Instant JChem) as quarterly updates. Two mobile apps, iKinase and iKinasePro ${ }^{25}$, are also available for download which enable basic search access into KKB content, including kinase inhibitor structures, biological data and references/patents. Simple substructure and exact structure search access into the $\mathrm{KKB}$ is also available. We have extracted from the $\mathrm{KKB} \sim 258 \mathrm{~K}$ structure activity data points and $\sim 76 \mathrm{~K}$ associated unique chemical structures across eight kinase targets and made these data freely available for download within this datanote to foster algorithms development and validation worldwide.

\section{Data availability}

F1000Research: Dataset 1. High quality, small molecule-activity for kinase research, 10.5256/f1000research.8950.d124591 $1^{36}$ 
Author contributions

RS, SCS and SMM contributed equally to the work.

Competing interests

No competing interests were disclosed.
Grant information

The work of SCS was supported by grant U54CA189205 (Illuminating the Druggable Genome Knowledge Management Center, IDG-KMC). The IDG-KMC is a component of the Illuminating the Druggable Genome (IDG) project and NIH Common Fund project, awarded by the NCI.
1. Cohen P: The origins of protein phosphorylation. Nat Cell Biol. 2002; 4(5): E127-130.

PubMed Abstract | Publisher Full Text

2. Fleuren $\mathrm{ED}$, Zhang $\mathrm{L}, \mathrm{Wu} J$, et al.: The kinome 'at large' in cancer. Nat Rev Cancer. 2016; 16(2): 83-98.

PubMed Abstract | Publisher Full Text

3. Mahajan K, Mahajan NP: Cross talk of tyrosine kinases with the DNA damage signaling pathways. Nucleic Acids Res. 2015; 43(22): 10588-601. PubMed Abstract | Publisher Full Text | Free Full Text

4. Tavares MR, Pavan IC, Amaral CL, et al.: The S6K protein family in health and disease. Life Sci. 2015; 131: 1-10. PubMed Abstract | Publisher Full Text

5. Hage-Sleiman R, Hamze AB, Reslan L, et al:: The Novel PKC $\theta$ from benchtop to clinic. J Immunol Res. 2015; 2015: 348798. PubMed Abstract | Publisher Full Text | Free Full Text

6. Chen $\mathrm{Q}$, Luo $\mathrm{H}$, Zhang $\mathrm{C}$, et al.: Bioinformatics in protein kinases regulatory network and drug discovery. Math Biosci. 2015; 262: 147-56. PubMed Abstract | Publisher Full Text

7. Chang E, Abe J: Kinase-SUMO networks in diabetes-mediated cardiovascular disease. Metabolism. 2016; 65(5): 623-33.

PubMed Abstract | Publisher Full Text

8. Cicenas J, Cicenas E: Multi-kinase inhibitors, AURKs and cancer. Med Oncol. 2016; 33(5): 43.

PubMed Abstract | Publisher Full Text

9. Hohenforst-Schmidt W, Zarogoulidis P, Steinheimer M, et al:: Tyrosine Kinase Inhibitors for the Elderly. J Cancer. 2016; 7(6): 687-93. PubMed Abstract | Publisher Full Text | Free Full Text

10. Gharwan $\mathrm{H}$, Groninger $\mathrm{H}$ : Kinase inhibitors and monoclonal antibodies in oncology: clinical implications. Nat Rev Clin Oncol. 2016; 13(4): 209-27. PubMed Abstract | Publisher Full Text

11. Wu P, Nielsen TE, Clausen MH: Small-molecule kinase inhibitors: an analysis of FDA-approved drugs. Drug Discov Today. 2016; 21(1): 5-10. PubMed Abstract | Publisher Full Text

12. Cai A, Li L, Zhou Y: Pathophysiological effects of RhoA and Rho-associated kinase on cardiovascular system. J Hypertens. 2016; 34(1): 3-10. PubMed Abstract | Publisher Full Text

13. Yamaoka K: Janus kinase inhibitors for rheumatoid arthritis. Curr Opin Chem Biol. 2016; 32: 29-33.

PubMed Abstract | Publisher Full Text

14. Braegelmann $C$, Hölzel M, Ludbrook V, et al:: Spleen tyrosine kinase (SYK) is a potential target for the treatment of cutaneous lupus erythematosus patients. Exp Dermatol. 2016; 25(5): 375-9. PubMed Abstract | Publisher Full Text

15. Yarza R, Vela S, Solas M, et al:: c-Jun N-terminal Kinase (JNK) Signaling as a Therapeutic Target for Alzheimer's Disease. Front Pharmacol. 2016; 6: 321. PubMed Abstract | Publisher Full Text | Free Full Text

16. McCormack PL: Pazopanib: a review of its use in the management of advanced renal cell carcinoma. Drugs. 2014; 74(10): 1111-25. PubMed Abstract | Publisher Full Text

17. Norman RA, Toader D, Ferguson AD: Structural approaches to obtain kinase selectivity. Trends Pharmacol Sci. 2012; 33(5): 273-8. PubMed Abstract | Publisher Full Text

18. Noble ME, Endicott JA, Johnson LN: Protein kinase inhibitors: insights into drug design from structure. Science. 2004; 303(5665): 1800-5

PubMed Abstract | Publisher Full Text

19. Karaman MW, Herrgard S, Treiber DK, et al.: A quantitative analysis of kinase inhibitor selectivity. Nat Biotechnol. 2008; 26(1): 127-32.

PubMed Abstract | Publisher Full Text

20. Fabian MA, Biggs WH 3rd, Treiber DK, et al:: A small molecule-kinase interaction map for clinical kinase inhibitors. Nat Biotechnol. 2005; 23(3): 329-36. PubMed Abstract | Publisher Full Text

21. Davis MI, Hunt JP, Herrgard S, et al:: Comprehensive analysis of kinase inhibitor selectivity. Nat Biotechnol. 2011; 29(11): 1046-51.

PubMed Abstract | Publisher Full Text

22. Willighagen EL, Waagmeester A, Spjuth $\mathrm{O}$, et al:: The ChEMBL database as linked open data. J Cheminform. 2013; 5(1): 23.

PubMed Abstract | Publisher Full Text | Free Full Text

23. Balakin KV, Tkachenko SE, Kiselyov AS, et al.: Focused chemistry from annotated libraries. Drug Discov Today Technol. 2006; 3(4): 397-403. Publisher Full Text

24. Samwald M, Jentzsch A, Bouton C, et al.: Linked open drug data for pharmaceutical research and development. J Cheminform. 2011; 3(1): 19. PubMed Abstract | Publisher Full Text | Free Full Text

25. Williams AJ, Ekins S, Clark AM, et al.: Mobile apps for chemistry in the world of drug discovery. Drug Discov Today. 2011; 16(21-22): 928-39. PubMed Abstract | Publisher Full Text

26. Oprea TI, Tropsha A: Target, chemical and bioactivity databases - integration is key. Drug Discov TodayTechnol. 2006; 3(4): 357-365. Publisher Full Text

27. Tuccinardi T, Martinelli A: Protein kinase homology models: recent developments and results. Curr Med Chem. 2011; 18(19): 2848-53. PubMed Abstract | Publisher Full Text

28. Hambly K, Danzer J, Muskal S, et al.: Interrogating the druggable genome with structural informatics. Mol Divers. 2006; 10(3): 273-81. PubMed Abstract | Publisher Full Text

29. Pieper U, Webb BM, Dong GQ, et al:: ModBase, a database of annotated comparative protein structure models and associated resources. Nucleic Acids Res. 2014; 42(Database issue): D336-46. PubMed Abstract | Publisher Full Text | Free Full Text

30. Lawless MS, Waldman M, Fraczkiewicz R, et al.: Using Cheminformatics in Drug Discovery. Handb Exp Pharmacol. 2016; 232: 139-68. PubMed Abstract | Publisher Full Text

31. Kuhn B, Guba W, Hert J, et al.: A Real-World Perspective on Molecular Design. J Med Chem. 2016; 59(9): 4087-102. PublMed Abstract | Publisher Full Text

32. Karthikeyan M, Vyas R: Role of Open Source Tools and Resources in Virtual Screening for Drug Discovery. Comb Chem High Throughput Screen. 2015; 18(6): 528-43. PubMed Abstract | Publisher Full Text

33. Schürer SC, Muskal, SM: Kinome-wide activity modeling from diverse public high-quality data sets. J Chem Inf Model. 2013; 53(1): 27-38. PubMed Abstract | Publisher Full Text | Free Full Text

34. Abeyruwan S, Vempati UD, Küçük-McGinty $\mathrm{H}$, et al:: Evolving BioAssay Ontology (BAO): modularization, integration and applications. J Biomed Semantics. 2014; 5(Suppl 1 Proceedings of the Bio-Ontologies Spec Interest G): S5 PubMed Abstract | Publisher Full Text | Free Full Text

35. Vempati UD, Przydzial MJ, Chung C, et al.: Formalization, annotation and analysis of diverse drug and probe screening assay datasets using the BioAssay Ontology (BAO). PLoS One. 2012; 7(11): e49198. PubMed Abstract | Publisher Full Text | Free Full Text

36. Muskal S, Sharma R, Schürer S: Dataset 1 in: High Quality, Small MoleculeActivity Datasets for Kinase Research. F1000Research. 2016. Data Source 


\section{Open Peer Review}

\section{Current Peer Review Status:}

\section{Version 1}

Reviewer Report 08 July 2016

https://doi.org/10.5256/f1000research.9629.r14358

(C) 2016 Avram S. This is an open access peer review report distributed under the terms of the Creative Commons Attribution License, which permits unrestricted use, distribution, and reproduction in any medium, provided the original work is properly cited.

\section{Sorin Avram}

Department of Computational Chemistry, Institute of Chemistry Timisoara of the Romanian Academy (ICT), Timișoara, Romania

The paper describes Kinase Knowledgebase (KKB), i.e., a database containing structure-activity data on kinases. The current data note briefly presents the KKB Q1 2016 Release and the appended eight kinase data sets, which are made hereby publicly available.

Kinases are valuable targets for many diseases, especially cancers. The subject is of real scientific. In general, the amount of bioactivity data, coming from various sources (scientific literature, highthroughput screening results, patents etc), is heterogeneous and a proper curation and standardization of the data can provide reliable activity points. These data may be employed in many ways as described by the authors. In my opinion, the main applications for a database such as KKB would be to build predictors to search the chemical space for new kinase inhibitors, and further to optimize the selectivity of kinase inhibitors. Currently, ChEMBL's ${ }^{1}$ publicly available Kinase SARfari (https://www.ebi.ac.uk/chembl/sarfari/kinasesarfari), provides a standard source for these tasks, covering about 532155 bioactivity data points i.e., version: 6.00- accessed June 20, 2016. This is less than one third of the 1.8 million KKB activity data point reported by the authors. In these circumstances, KKB might add valuable information for kinase research. Finally, the future analysis and employment of the eight data sets made freely available in the current note will provide a clearer view of the potential and versatility of KKB.

There would be two minor observations:

1. The methodology used to generate the data is described in the first paragraph in the section entitled "Kinase Knowledgebase (KKB)". In order to be more accessible for the reader, this paragraph should be encompassed in a separate section named "Materials and methods".

2. In Table 2 there are three columns with repeated headers. In order to remove any doubts, I would recommend the authors to clarify this issue.

Otherwise, the data note is well written, kinases are indexed using the widely adopted Uniprot IDs and the references are updated. 
I recommend this data note for indexation and would like the authors to address the minor observations.

\section{References}

1. Bento AP, Gaulton A, Hersey A, Bellis LJ, et al.: The ChEMBL bioactivity database: an update. Nucleic Acids Res. 2014; 42 (Database issue): D1083-90 PubMed Abstract | Publisher Full Text

Competing Interests: No competing interests were disclosed.

\section{I confirm that I have read this submission and believe that I have an appropriate level of expertise to confirm that it is of an acceptable scientific standard.}

Reviewer Report 08 July 2016

\section{https://doi.org/10.5256/f1000research.9629.r14833}

(C) 2016 Nicola G. This is an open access peer review report distributed under the terms of the Creative Commons Attribution License, which permits unrestricted use, distribution, and reproduction in any medium, provided the original work is properly cited.

\section{George Nicola}

Computational Biology, University of California at San Diego, San Diego, CA, USA

This article describes an overview of current kinase-related databases of significance, with particular focus on the contents of the Kinase Knowledgebase (KKB). The KKB has the largest repository of high-quality kinase activity data. Providing access to over $1 / 4$ million data points on several of the most important kinases allows for an exciting insight into the relevance of these validated drug targets and the diversity of compounds affecting them. It is a promising trend that private companies are unlocking their proprietary data troves for the advancement of academic research. This is a nice Data Note that merits indexing in F1000Research.

A few minor typographical corrections:

Table 2: Three of the column names seem to be duplicated.

Table 2: It is unclear what the grey vs white rows represent in 'Kinase Classification' and 'Family' columns. If only for readability, perhaps these should alternate.

Section 'Kinase inhibitor datasets' at the end of the first paragraph: The word 'respectively' is not needed.

Section 'Kinase inhibitor datasets' $4^{\text {th }}$ paragraph, ' 54K inhibitors molecules': 'inhibitors' does not need to be plural.

Figures 1 \& 2:I would use the word 'Breakdown' instead of 'Breakup'.

Figure 2: Are 'Cell-Free' and 'Animal Model' truly zero percent? If so, they should be 
excluded; if not, the fractional percent should be listed.

'Conclusions': 'datanote' should be two words, to be consistent with the F1000 article type.

Competing Interests: No competing interests were disclosed.

I confirm that I have read this submission and believe that I have an appropriate level of expertise to confirm that it is of an acceptable scientific standard.

The benefits of publishing with F1000Research:

- Your article is published within days, with no editorial bias

- You can publish traditional articles, null/negative results, case reports, data notes and more

- The peer review process is transparent and collaborative

- Your article is indexed in PubMed after passing peer review

- Dedicated customer support at every stage

For pre-submission enquiries, contact research@f1000.com 